\title{
Fermentation Quality and in Vitro Nutrient Digestibility of Fresh Rice Straw-Based Silage Treated with Lactic Acid Bacteria
}

\author{
B. Santoso ${ }^{\mathrm{a}, *}$, B. Tj Hariadii, V. Sabariah ${ }^{\mathrm{b}}$, \& T. Sraun ${ }^{\mathrm{a}}$ \\ ad Department of Animal Nutrition, Faculty of Animal Science, Fishery and Marine Science, \\ The State University of Papua \\ bepartment of Fishery, Faculty of Animal Science, Fishery and Marine Science, The State University of Papua \\ Jln. Gunung Salju, Amban, Manokwari - Papua Barat, 98314, Indonesia \\ (Received 01-04-2014; Reviewed 28-04-2014; Accepted 12-08-2014)
}

\begin{abstract}
The aim of the experiment was to evaluate fermentation characteristics and in vitro nutrient digestibility of fresh rice straw-based silage ensiled with addition of epiphytic lactic acid bacteria (LAB) inoculant. The experiment was arranged in a completely randomized design, with $2 \times 2$ factorial arrangement of treatments. The first factor was the ratio of fresh rice straw (FRS), tofu waste (TW) and cassava waste (CW) consisted of two levels i.e., $40: 20: 40$ and $40: 25: 35$, on dry matter (DM) basis). The second factor was the level of LAB inoculant with two levels ie., 0 and $20 \mathrm{~mL} / \mathrm{kg}$ FM. The treatments were (A) FRS + TW + CW with the ratio of $40: 20: 40$, without LAB inoculant; (B) FRS + TW + CW with the ratio of $40: 20: 40+$ LAB inoculant; (C) FRS + TW + CW with the ratio of $40: 25$ : 35, without LAB inoculant; (D) FRS + TW + CW with ratio of $40: 25: 35+$ LAB inoculant. Results showed that addition of LAB inoculant in silage increased lactic acid concentration $(P<0.01)(3.7 \%$ vs. $5.2 \%$ fresh matter $(\mathrm{FM})$ and $\mathrm{V}$-score $(84.6$ vs. 89.6) $(\mathrm{P}<0.05)$. Concentrations of lactic acid and V-score were higher in silages with high cassava waste $(\mathrm{A}$ and $\mathrm{B})(\mathrm{P}<0.05)$ compared to silage with low cassava waste (C and D). The IVOMD of rice straw-based silage was affected by the ratio of silage materials and the level of $\mathrm{LAB}$ inoculant $(\mathrm{P}<0.01)$. There was no interaction between the ratio of silage materials and the level of $\mathrm{LAB}$ inoculant $(\mathrm{P}>0.05)$ on chemical composition, fermentation quality of silage and in vitro digestibility. It was concluded that mixture silage with ratio of $40: 20: 40$ with the addition of LAB inoculant had the best fermentation quality and nutrient digestibility than other silages.
\end{abstract}

Key words: digestibility, fermentation, lactic acid, fresh rice straw, silage

\section{ABSTRAK}

Tujuan penelitian ini untuk mengevaluasi karakteristik fermentasi dan kecernaan nutrien (in vitro) silase berbasis jerami padi segar yang diensilase dengan penambahan bakteri asam laktat (BAL) epifit. Percobaan ini disusun dalam rancangan acak lengkap pola faktorial $2 \times 2$. Dua faktor perlakuan, yaitu rasio jerami padi segar : ampas tahu : onggok (40: $20: 40$ dan $40: 25: 35$, berdasarkan bahan kering (BK)) dan 2 level inokulan BAL (0 dan $20 \mathrm{ml} / \mathrm{kg}$ bahan segar). Perlakuan terdiri atas (A) jerami padi segar + ampas tahu + onggok (40:20:40, berdasarkan bahan kering); (B) jerami padi segar + ampas tahu + onggok $(40: 20: 40)$ + inokulan BAL; (C) jerami padi segar + ampas tahu + onggok (40: $25: 35)$; jerami padi segar + ampas tahu + onggok (40:25:35) + inokulan BAL. Hasil percobaan menunjukkan bahwa penambahan inokulan BAL pada silase meningkatkan konsentrasi asam laktat $(3,7 \%$ vs. $5,2 \%$ bahan segar $)(P<0,01)$ dan $V$-score $(84,4$ vs. 89,6$)(\mathrm{P}<0,05)$. Konsentrasi asam laktat dan $V$-score lebih tinggi pada silase dengan kadar onggok tinggi $(\mathrm{A}$ dan $\mathrm{B})(\mathrm{P}<0,05)$ dibandingkan dengan silase dengan kadar onggok rendah (C dan D). Kecernaan bahan organik secara in vitro dipengaruhi oleh rasio bahan silase dan level inokulan BAL $(P<0,01)$. Tidak terdapat interaksi antara rasio bahan silase dan level inokulan BAL $(P>0,05)$ pada komposisi kimia, kualitas fermentasi dan kecernaan secara in vitro. Disimpulkan bahwa silase dengan rasio $40: 20: 40$ dengan penambahan inokulan BAL mempunyai kualitas fermentasi dan kecernaan nutrien terbaik dibandingkan silase lain.

Kata kunci: kecernaan, fermentasi, asam laktat, jerami padi segar, silase

*Corresponding author:

E-mail: santosob@lycos.com 


\section{INTRODUCTION}

Recently, there is a growing interest in the use of agricultural and food processing industry residues as silage materials. Fresh rice straw (FRS) is the lower part of the rice crop harvested and remained at the rice field. These residues are abundantly available, and most of it are not used as livestock feeds and later are burned. Burned rice straw is then flown to the air and the smoke produced causes air pollution. Li et al. (2010) and Zhang et al. (2010) reported that rice straw (RS) had potential to be preserved as silage and used as ruminant feeds. However, successful rice straw ensiling is difficult due to low water soluble carbohydrates (WSC) and less epiphytic LAB (Kawamoto et al., 2007). Li et al. (2010) reported that WSC content of rice straw averaged $19 \mathrm{~g} / \mathrm{kg}$ of fresh weight. As a general rule, a concentration of 30 $\mathrm{g} \mathrm{WSC} / \mathrm{kg}$ fresh weight is necessary to reduce the risk of secondary fermentation (Chamberlain \& Wilkinson, 1996). Sugar-rich materials are commonly used as effective additives for ensiling crops that have low WSC. Cassava waste $(\mathrm{CW})$ is a solid residue produced from cassava powder industry with its primary component of starch. Besides, tofu waste (TW) is a residue resulted from tofu processing and contains high crude protein $(\mathrm{CP})$ on dry matter (DM) basis i.e. $21.8 \pm 4.5 \%$, and therefore it can be used as a protein source for livestock (Santoso \& Hariadi, 2009).

The lactic acid bacteria (LAB) play an important role in silage fermentation and influence silage quality. Under natural circumstances, LAB grows as epiphytic bacteria. However, the population of LAB is usually low and varies with standing crops. Thus, addition of LAB inoculant is needed to improve silage quality (Bureenok et al., 2006). In the previous studies, Yahaya et al. (2004); Bureenok et al. (2006); and Santoso et al. (2011a) stated that tropical and temperate forages ensiled with addition of epiphytic LAB inoculant resulted a better fermentation quality as compared to commercial inoculant. Santoso et al. (2009) found that lactic acid concentration in grass silage treated with $2 \%(\mathrm{v} / \mathrm{w})$ of epiphytic LAB inoculant from king grass was higher than silage with addition of LAB inoculant from elephant grass. Similar result was reported in other experiments by Antaribaba et al. (2009) and Santoso et al. (2011b) that king grass silage and rice crop residue-based silage with addition of epiphytic LAB prepared from king grass had good fermentation quality as compared to control silage. Moreover, Horiguchi \& Takahashi (2007) concluded that fermentation quality of green soybean stover silage was improved by addition of $5 \%(\mathrm{v} / \mathrm{w})$ fermented juice lactic bacteria prepared from green soybean stover. This experiment was carried out to evaluate fermentation characteristic and in vitro nutrient digestibility of rice straw-based silage treated with addition of epiphytic LAB inoculant extracted from king grass.

\section{MATERIALS AND METHODS}

\section{Inoculant Preparation}

The epiphytic LAB inoculant was prepared according to Bureenok et al. (2006) as was modified by by
Santoso et al. (2009); Santoso et al. (2011a); and Santoso et al. (2012). A $220 \mathrm{~g}$ of fresh king grass was macerated in $1000 \mathrm{~mL}$ of distilled water by using a high-speed blender for $4 \mathrm{~min}$. The maceration was filtered through two layers of cheesecloths, and $600 \mathrm{~mL}$ of filtrate was collected in erlenmeyer containing $18 \mathrm{~g}$ of glucose. The filtrate was mixed and incubated anaerobically at $30^{\circ} \mathrm{C}$ for $48 \mathrm{~h}$.

\section{Silage Materials and Preparation}

Fresh RS (Oryza sativa var. Mygongga) was collected from rice field area at Prafi District, Manokwari Regency. The TW and CW were obtained from small-scale food industry located at Prafi District. King grass was harvested at 50 days of regrowth defoliation from the experimental field of Faculty of Animal Science, Fishery and Marine Science, The State University of Papua in Manokwari.

Fresh RS (FRS) was chopped with a domestic cutter into 2-3 cm lengths. The TW and CW were dried by using oven at $60{ }^{\circ} \mathrm{C}$ for $48 \mathrm{~h}$ before being mixed with fresh FRS. The silages were arranged in a $2 \times 2$ factorial arrangement of treatments. The first factor was ratio of FRS, TW and CW with two levels i.e., $40: 20: 40$ and 40 : $25: 35$, on DM basis. The second factor was the level of LAB inoculant consisted of two levels i.e., 0 and $20 \mathrm{~mL} /$ $\mathrm{kg}$ FM. The treatments were (A) FRS + TW + CW (40:20 : 40) without LAB inoculant; (B) FRS + TW + CW (40:20 $: 40)+$ LAB inoculant; (C) FRS + TW + CW (40:25:35) without LAB inoculant; and (D) FRS + TW + CW (40:25 : 35)+ LAB inoculant. The FRS, TW and CW ratios used in this study were based on previous study by Santoso et al. (2012). The inoculant which contained $10^{6} \mathrm{cfu} / \mathrm{mL}$ was sprayed onto silage material and subsequently mixed by hand before packing into silos. About $1.5 \mathrm{~kg}$ of silage materials were packed into plastic silos (size $295 \times 495$ $\times 0.06 \mathrm{~mm}$ ) and tied with a string. Three replicate silos were prepared for each treatment and stored in room temperature (approximately $28{ }^{\circ} \mathrm{C}$ ) for $30 \mathrm{~d}$. Samples were collected for preparation of silage extract and sample analyses.

\section{In Vitro Digestibility}

Determinations of DM and organic matter (OM) digestibility were conducted by using in vitro procedure as previously described by Hariadi \& Santoso (2010). Twenty five milliliters of rumen liquor-buffer mixture in a $1: 4(\mathrm{v} / \mathrm{v})$ ratio were dispensed in $100 \mathrm{~mL}$ glass tubes containing $250 \mathrm{mg}$ of dry sample. Triplicates of blank (with no feed sample) and standard (Pangola grass) were included in each run. Rumen liquor was obtained from two ruminally fistulated Holstein Friesian crossbred cows fed elephant grass twice a day at maintenance level of DM intake. Rumen liquor was collected in the morning before feeding, mixed and strained through four layers of cheesecloth into a pre-warmed thermos flask. Buffer solution was prepared by dissolving $9.8 \mathrm{~g}$ $\mathrm{NaHCO}_{3}, 9.3 \mathrm{~g} \mathrm{NaHPO}_{4} .12 \mathrm{H}_{2} \mathrm{O}, 0.47 \mathrm{~g} \mathrm{NaCl}, 0.57 \mathrm{~g} \mathrm{KCl}$, $0.04 \mathrm{CaCl}_{2}, 0.12 \mathrm{~g} \mathrm{MgSO} .7 \mathrm{H}_{2} \mathrm{O}$ per $1000 \mathrm{~mL}$ distilled water. After gassing $\mathrm{CO}_{2}$ in the tube, corks were tightly placed over the tubes and were incubated in a water bath at $39^{\circ} \mathrm{C}$ for $48 \mathrm{~h}$. After $48 \mathrm{~h}$ of microbial incubation, 
the samples were incubated at $39^{\circ} \mathrm{C}$ for $48 \mathrm{~h}$ with acidpepsin. Therefore, the contents were filtered through pre-weighed Gooch crucibles and dried at $105^{\circ} \mathrm{C}$ for $24 \mathrm{~h}$. The percent loss of weight was determined and presented as in vitro DM digestibility (IVDMD). The left residue was ashed at $550{ }^{\circ} \mathrm{C}$ for determination of in vitro OM digestibility (IVOMD).

\section{Chemical Analysis and Microbial Count}

Dried samples were used to determine DM, OM and CP according to procedure of AOAC (2005). The fiber content i.e., neutral detergent fiber (NDF) and acid detergent fiber (ADF) were analyzed by using Van Soest et al. (1991) method with some modification i.e., NDF was determined without the use of $\infty$-amylase and sodium sulfite.

The numbers of LAB were counted by pour-plate technique in de Man, Rogosa and Sharpe agar. The plates were incubated at $35^{\circ} \mathrm{C}$ for $3 \mathrm{~d}$ (Bureenok et al., 2006).

\section{Preparation of Silage Extract}

A $20 \mathrm{~g}$ of silage was macerated in $70 \mathrm{~mL}$ of distilled water and stored at $4{ }^{\circ} \mathrm{C}$ for $24 \mathrm{~h}$. The maceration was then homogenized for $15 \mathrm{~min}$ by using a shaker and filtered through a Whatman No. 1542 filter paper. The filtrate was used for determination of $\mathrm{pH}$, volatile fatty acids (VFAs), and lactic acid and $\mathrm{NH}_{3}-\mathrm{N}$. The $\mathrm{pH}$ value was determined by using a pH meter (Hanna Hi 9025, Romania). Concentrations of individual VFAs were analyzed by using gas chromatography (Varian CP-9002 GC, Shimadzu, Japan) equipped with flame ionization detector (FID) and stainless steel column $(1500 \mathrm{~mm} \times 3$ $\mathrm{mm}$ i.d). Nitrogen was used as carrier gas at $1.25 \mathrm{~kg} / \mathrm{cm}^{2}$ pressure. The temperatures of injector oven, column oven and detector were 220,130 , and $220^{\circ} \mathrm{C}$, respectively as were previously described by Santoso et al. (2012). Concentrations of lactic acid and $\mathrm{NH}_{3}-\mathrm{N}$ were analyzed according to colorimetric and Conway methods, respectively as was described by Santoso et al. (2011a) and Santoso et al. (2012). To assess the quality of the silage, the V-Score was calculated from the $\mathrm{NH}_{3}-\mathrm{N} /$ Total $\mathrm{N}$ and VFA concentration in the silages (Takahashi et al., 2005).

\section{Calculations and Statistical Analysis}

Data were analyzed as completely randomized design with a $2 \times 2$ factorial arrangement of treatments, using GLM procedure of SAS (SAS Institute Inc., Cary, NC). The linear model used for each dependent variable accounted for the effects of silage materials ratio (S), level of LAB inoculant (L), and $\mathrm{S} \times \mathrm{L}$ interaction as fixed effects.

\section{RESULTS AND DISCUSSION}

\section{Characteristics of King Grass Extract}

The $\mathrm{pH}$ value and $\mathrm{LAB}$ number in king grass extract before and after $48 \mathrm{~h}$ of incubation are shown in Table 1 .
Table 1. Changes of $\mathrm{pH}$ value and LAB number in king grass extract before and after $48 \mathrm{~h}$ of incubation

\begin{tabular}{lcc}
\hline & Before incubation & After incubation \\
\hline $\mathrm{pH}$ & 6.64 & 4.63 \\
$\mathrm{LAB}\left(\times 10^{6} \mathrm{cfu} / \mathrm{mL}\right)$ & 1.60 & 6.30 \\
\hline
\end{tabular}

The number of LAB in king grass extract after $48 \mathrm{~h}$ of incubation increased 4-fold as compared to that before incubation. However, after $48 \mathrm{~h}$ of anaerobic incubation, king grass extract had a low $\mathrm{pH}$ compared to that before incubation. This result indicated that LAB produced high lactic acid concentration during incubation which resulted in low $\mathrm{pH}$ value. This result was consistent with previous studies by Santoso et al. (2011a) and Santoso et al. (2012) that $\mathrm{pH}$ value in king grass extract declined from 6.71 to 3.51 and from 6.81 to 3.29 , respectively after incubation at $30^{\circ} \mathrm{C}$ for $48 \mathrm{~h}$. The declined trend in $\mathrm{pH}$ value with the increased LAB number in extracts of grass and legume after $48 \mathrm{~h}$ of incubation were also reported by Bureenok et al. (2006) and Wang et al. (2009).

\section{Chemical Composition of Silages}

The nutrients content of rice straw-based silage treated with epiphytic LAB inoculant are presented in Table 2. The moisture content of silages in this study varied from $65.6 \%$ to $67.7 \%$ which was lower than moisture content of green soybean stover silage with addition of fermented juice of lactic acid bacteria (FJLB) (Horiguchi \& Takahashi, 2007). In a study by Takahashi et al. (2005), moisture content of whole rice crop silage treated with FJLB was $51.9 \%$. However, addition of dried TW and CW containing low moisture i.e., 13.6\% and $13.9 \%$, respectively, may have benefited in increasing DM content of silages from $21.5 \%$ to $34 \%$. The DM contents in all silages were higher than the value of $30 \%$ for ideal silage as suggested by Chamberlain \& Wilkinson (1996). However, the fermentation was also shown to be improved when fresh rice straw was mixed with low moisture CW. Organic matter content of silages increased $(\mathrm{P}<0.05)$ with the increased proportion of $\mathrm{CW}$ from $35 \%$ to $40 \%$. The proportion of fibrous components i.e., NDF and ADF were significantly lower for silage added $L A B$ inoculant $(B$ and $D)(P<0.05)$ than silage without $\mathrm{LAB}$ inoculant (A and $\mathrm{C}$ ), meanwhile hemicellulose content was higher in silages with LAB inoculant addition $(\mathrm{P}<0.05)$. One of the explanations for the lower NDF and ADF in those silages was that enzymatic actions e.g. hemicellulase and cellulase present in the original forage degraded the cell wall during ensiling (Yahaya et al., 2004 and de Oliveira et al., 2009). Another reason was the fibrous component that was hydrolyzed and many of the organic acids such as lactic acid and acetic acid, were produced during ensilaging (Cao et al., 2010). Similar results were also reported in other experiments using guinea grass, rice straw and king grass silages (Ando et al., 2006; Li et al., 2010; Santoso et al., 2011a). This was also consistent with the results obtained from ensiling of straws of three varieties rice, namely Wuyunjing7, Wuyujing3, and Jinglingxiang 
Table 2. Chemical Composition (\%) of fresh rice straw and fresh rice straw-based silages

\begin{tabular}{|c|c|c|c|c|c|c|c|c|c|}
\hline & \multirow{2}{*}{$\mathrm{FRS}^{1}$} & \multicolumn{4}{|c|}{ Silages $^{2}$} & \multirow{2}{*}{ SEM $^{3}$} & \multicolumn{3}{|c|}{ P-values ${ }^{4}$} \\
\hline & & $\mathrm{A}$ & B & $\mathrm{C}$ & $\mathrm{D}$ & & $S$ & $\mathrm{~L}$ & $\mathrm{~S} \times \mathrm{L}$ \\
\hline Moisture & 79.5 & 67.4 & 65.6 & 67.7 & 67.3 & 1.26 & 0.49 & 0.32 & 0.62 \\
\hline Organic matter & 87.5 & 90.4 & 90.9 & 89.1 & 89.5 & 0.54 & 0.04 & 0.41 & 0.93 \\
\hline Crude protein & 7.5 & 9.8 & 9.8 & 10.2 & 10.5 & 0.49 & 0.30 & 0.74 & 0.79 \\
\hline NDF & 77.5 & 55.7 & 52.4 & 53.1 & 51.9 & 0.94 & 0.13 & 0.04 & 0.30 \\
\hline $\mathrm{ADF}$ & 53.0 & 41.3 & 37.8 & 42.9 & 40.1 & 1.03 & 0.10 & 0.02 & 0.71 \\
\hline Hemicellulose & 7.5 & 14.4 & 14.6 & 10.1 & 11.8 & 0.44 & $<0.01$ & 0.05 & 0.10 \\
\hline
\end{tabular}

Note:

${ }^{1}$ Fresh rice straw

${ }^{2}$ (A) FRS + TW + CW (40: $20: 40$, on dry matter basis); (B) FRS + TW + CW (40: $\left.20: 40\right)+$ LAB inoculant; (C) FRS + TW + CW (40 : $\left.25: 35\right)$; (D) FRS + TW

+ CW $(40: 25: 35)+$ LAB inoculant

${ }^{3}$ Standard error of mean

${ }^{4} \mathrm{~S}$ : effect of silage materials ratio; L: effect of LAB; $\mathrm{S} \times \mathrm{L}$ : interaction between $\mathrm{S}$ and $\mathrm{L}$.

treated with LAB inoculant and glucose (Li et al., 2010). However, silages with low content of CW (C and D) had lower $(\mathrm{P}<0.01)$ hemicellulose content than silages with high content of $\mathrm{CW}$ (A and $\mathrm{B})$.

\section{Fermentative Quality of Silages}

The fermentation characteristics of FRS-based silage treated with epiphytic LAB inoculant is presented in Table 3. The $\mathrm{pH}$ value of silage was affected by the ratio of silage materials $(\mathrm{P}<0.01)$ and the level of LAB inoculant $(\mathrm{P}<0.05)$. There was no interaction $(\mathrm{P}>0.05)$ between the ratio of silage materials and the level of LAB. In our research, $\mathrm{pH}$ values in all silages were within the ideal range of 4.0 to 4.5 as was suggested by Chamberlain \& Wilkinson (1996). Silage supplemented with LAB inoculant $(\mathrm{B}$ and $\mathrm{D})$ had lower $\mathrm{pH}$ value $(\mathrm{P}<0.05)$ than silage non supplemented with LAB inoculant (A and C). Addition of epiphytic LAB inoculant at ensiling ensured a rapid fermentation which resulted in quick accumulation of lactic acid and low $\mathrm{pH}$ at early stages of ensiling. Silage with high content of CW (A and B) had lower $\mathrm{pH}$ value $(\mathrm{P}<0.01)$ compared to silages $\mathrm{C}$ and $\mathrm{D}$. Higher lactic acid in silage with $40 \%$ of CW could be attributed to the higher availability of soluble carbohydrate content, thus resulted in high lactic acid concentration produced by LAB. Lower $\mathrm{pH}$ value in silages contained $40 \%$ of $\mathrm{CW}$ or silages treated with $\mathrm{LAB}$ inoculant was supported by the higher lactic acid concentrations $(\mathrm{P}<0.01)$ in those silages. Danner et al. (2003) stated that lactic acid was the strongest of all silage acids and its presence would decrease the $\mathrm{pH}$ more effectively than the other VFAs. This result is consistent with previous studies using rice crop residue treated with epiphytic LAB as reported by Takahashi et al. (2005) and Santoso et al. (2011b). Study reported by Cao et al. (2010) showed that the whole crop rice silage added with L. plantarum had higher lactic acid concentration than molasses and control silages. McDonald et al. (1991) revealed that reducing $\mathrm{pH}$ silage prevented the growth of undesirable microbes e.g., listeria, clostridia, enterobacteriaceae and moulds that caused a secondary fermentation during ensilage. Sebolai et al. (2012) stated that high lactic acid concentration of silage had beneficial for ruminant because Megasphaera elsdenii metabolized lactic acid into propionic acid and then was used as a precursor for gluconeogenesis. In addition, LAB inoculant from silage has a potential role as a probiotic which beneficially affects the host animal by improving its intestinal microbial balance (Weinberg et al., 2004).

Table 3. Fermentation characteristics of fresh rice straw-based silage after 30 days of ensilage

\begin{tabular}{|c|c|c|c|c|c|c|c|c|}
\hline & \multicolumn{4}{|c|}{ Silages $^{1}$} & \multirow{2}{*}{$\mathrm{SEM}^{2}$} & \multicolumn{3}{|c|}{ P-values ${ }^{3}$} \\
\hline & $\mathrm{A}$ & $\mathrm{B}$ & $\mathrm{C}$ & $\mathrm{D}$ & & $S$ & $\mathrm{~L}$ & $\mathrm{~S} \times \mathrm{L}$ \\
\hline $\mathrm{pH}$ & 4.13 & 3.97 & 4.26 & 4.19 & 0.04 & 0.01 & 0.03 & 0.11 \\
\hline \multicolumn{9}{|l|}{ Organic acids (\% FM) } \\
\hline Lactic acid & 4.10 & 6.70 & 3.30 & 3.80 & 0.55 & 0.01 & 0.01 & 0.10 \\
\hline Acetic acid & 0.70 & 0.63 & 1.10 & 0.85 & 0.12 & 0.05 & 0.25 & 0.50 \\
\hline Propionic acid & 0.03 & 0.03 & 0.10 & 0.05 & 0.03 & 0.28 & 0.58 & 0.51 \\
\hline Butyric acid & 0.06 & 0.04 & 0.17 & 0.08 & 0.03 & 0.05 & 0.17 & 0.36 \\
\hline Total VFAs & 0.80 & 0.73 & 1.40 & 0.95 & 0.12 & 0.01 & 0.11 & 0.16 \\
\hline Total VFAs/Total acids & 15.90 & 10.1 & 30.40 & 21.20 & 3.38 & $<0.01$ & 0.23 & 0.13 \\
\hline $\mathrm{NH}_{3}-\mathrm{N} /$ Total N (\%) & 5.80 & 3.70 & 5.20 & 5.10 & 0.60 & 0.54 & 0.19 & 0.16 \\
\hline V-score & 90.70 & 92.70 & 78.50 & 86.00 & 2.32 & 0.01 & 0.05 & 0.28 \\
\hline
\end{tabular}

Note:

${ }^{1}$ (A) FRS + TW + CW (40: $20: 40$, on dry matter basis); (B) FRS + TW + CW (40: $\left.20: 40\right)+$ LAB inoculant; (C) FRS + TW + CW (40 : 25 : 35); (D) FRS + TW

+ CW $(40: 25: 35)+$ LAB inoculant

${ }^{2}$ Standard error of mean

${ }^{3} \mathrm{~S}$ : effect of silage materials ratio; L: effect of LAB; S×L: interaction between $\mathrm{S}$ and $\mathrm{L}$.

FM: fresh matter 
The acetic acid concentration was lower in silages with $40 \%$ of CW (A and B) as compared to silages with $35 \%$ of $C W(C$ and $D)(P<0.05)$. This result indicated that the activity of hetero fermentative $\mathrm{LAB}$ in both silages $\mathrm{A}$ and $\mathrm{B}$ was lower than in silages $\mathrm{C}$ and D. McDonald et al. (1991) revealed that during ensiling, hexose was fermented to lactic acid and other products i.e., ethanol and acetic acid. In our research, silages with high content of CW (A and B) had lower butyric acid concentration $(\mathrm{P}<0.05)$ than silages $\mathrm{C}$ and $\mathrm{D}$. The results indicated that clostridia bacteria were more active in silages with low content of CW than in silages with high content of CW. According to Chamberlain \& Wilkinson (1996), secondary fermentation is occurred when insufficient acid is produced by the primary fermentation to reduce the $\mathrm{pH}$ to below a critical level of about 4.5. The bacteria responsible for secondary fermentations are mainly the clostridia. These bacteria may convert lactic acid to butyric, or they may degrade proteins, peptides and amino acids to amines and ammonia. McDonald et al. (1987) also reported that butyric acid was produced by saccharolytic clostridia i.e. Clostridium butyricum. Silage materials with ratio of $40: 20: 40$ had lower total VFAs concentration as compared to those with ratio of $40: 35$ : $35(\mathrm{P}<0.01)$. This finding indicated that silage containing FRS, TW and CW in a ratio of $40: 20: 40$ had better fermentative quality than those in a ratio of $40: 25: 35$. Chamberlain \& Wilkinson (1996) stated that the VFAs consisted of acetic acid, propionic acid, butyric acid and other acids. The production of these acids is a reflection of an inefficient fermentation or of secondary fermentation of lactic acid to butyric acid and degradation of amino acids to ammonia with the production of amino acid from the skeleton of the amino acid.

In the present study, the proportions of VFAs to total acid were $15.9 \%, 10.1 \%, 30.4 \%$, and $21.2 \%$, respectively for silage A, B, C and D. The result indicated that fermentations of silages $\mathrm{A}$ and $\mathrm{B}$ were better than silages $C$ and D. However, the values found in silages C and D were still above the ideal value of $20 \%$ as recommended by Chamberlain \& Wilkinson (1996). Percentage of $\mathrm{NH}_{3}$ $\mathrm{N} /$ Total $\mathrm{N}$ was not affected by silage materials ration and level of $L A B$ inoculant $(P>0.05)$. However, silage treated with $\mathrm{LAB}$ inoculant (B and $\mathrm{D})$ had slightly lower $\mathrm{NH}_{3}-\mathrm{N} / \mathrm{TN}$ than silage without LAB inoculant (A and C). In the previous work of Bureenok et al. (2006) who found that the use of fermented napier grass extract increased lactic acid and greatly inhibited the clostridial activity to protect proteins from extensive degradation.
As stated by Givens \& Rulquin (2004) that during ensiling, protein was degraded to peptides and free amino acids by plant proteases. In addition, degradation of amino acids to ammonia and non-protein nitrogenous fraction was predominantly due to proteolytic clostridia. Chamberlain \& Wilkinson (1996) concluded that ammonia- $\mathrm{N}$ was an indicator of the proportion of the total $\mathrm{N}$ which was completely degraded during ensiling. Hence, concentration of ammonia- $\mathrm{N}$ is the best indicator of secondary fermentation. The growth of proteolytic clostridia, which degrade protein and amino acids to $\mathrm{NH}_{3}$ is inhibited by low pH (McDonald et al., 1991; Givens \& Rulquin, 2004). This result was supported by the low $\mathrm{pH}$ values in silages $B$ and D compared to silages A and C. This condition could depress the growth of proteolytic clostridia.

The $\mathrm{V}$-score is one of indicator to evaluate the quality of silage. $\mathrm{V}$-scores in silages $\mathrm{A}$ and $\mathrm{B}$ were significantly higher than those in silages $C$ and $D(P<0.01)$, suggesting that silage with $40 \%$ of cassava waste had better fermentative quality as compared to silages with $35 \%$ of cassava waste. In addition, V-score found in the present study was comparable with the V-score of whole rice crop silage (Takahashi et al., 2005) and slightly lower than total mixed ration silage of whole crop rice (Cao et al., 2010).

\section{In Vitro Nutrient Digestibility}

Ratio of silage materials and level of epiphytic LAB inoculant had no effect on IVDMD value ( $P>0.05)$. On the other hand, IVOMD of rice straw-based silage was affected by the ratio of silage materials and LAB inoculant $(\mathrm{P}<0.01)$. However, the IVOMD increased by average of $7.3 \%$ when epiphytic LAB inoculant prepared from king grass was added. Increasing IVOMD in silages with addition of LAB inoculant in the present study could be due to the lower NDF and ADF contents. This result was supported by previous study by Ando et al. (2006) that addition of LAB increased the digestibility of DM, $\mathrm{OM}$, and $\mathrm{CP}$ of guinea grass silage. When compared to rice straw, the IVDMD and IVOMD in rice straw-based silage increased by average of $37.9 \%$ and $32.5 \%$, respectively. Silage with high CW content (A and B silages) had higher IVOMD value compared to low CW content ( $C$ and $D$ silages) $(\mathrm{P}<0.01)$, which may be due to a higher soluble carbohydrate content. In our study, there was no interaction between ratio of silage materials $(S)$ and level of $\mathrm{LAB}(\mathrm{L})$.

Table 4. In vitro $\mathrm{DM}$ and $\mathrm{OM}$ digestibility of rice straw and fresh rice straw-based silages

\begin{tabular}{|c|c|c|c|c|c|c|c|c|c|}
\hline & \multirow{2}{*}{$\mathrm{RS}^{1}$} & \multicolumn{4}{|c|}{ Silages $^{2}$} & \multirow{2}{*}{ SEM $^{3}$} & \multicolumn{3}{|c|}{$\mathrm{P}_{\text {-value }}{ }^{4}$} \\
\hline & & A & B & $\mathrm{C}$ & $\bar{D}$ & & $S$ & $\mathrm{~L}$ & $\mathrm{~S} \times \mathrm{L}$ \\
\hline IVDMD (\%) & 41.2 & 56.6 & 57.4 & 55.2 & 58.2 & 1.20 & 0.79 & 0.15 & 0.40 \\
\hline IVOMD (\%) & 48.3 & 65.0 & 69.9 & 58.8 & 62.8 & 0.75 & $<0.01$ & $<0.01$ & 0.58 \\
\hline
\end{tabular}

Note:

${ }^{1}$ Rice straw

${ }^{2}$ (A) FRS + TW + CW (40: $20: 40$, on dry matter basis); (B) FRS + TW + CW (40: $\left.20: 40\right)+$ LAB inoculant; (C) FRS + TW + CW (40 : $\left.25: 35\right) ;(D)$ FRS + TW

+ CW $(40: 25: 35)+$ LAB inoculant

${ }^{3}$ Standard error of mean

${ }^{4} \mathrm{~S}$ : effect of silage materials ratio; L: effect of LAB; $\mathrm{S} \times \mathrm{L}$ : interaction between $\mathrm{S}$ and $\mathrm{L}$. 


\section{CONCLUSION}

Addition of $\mathrm{LAB}$ inoculant to rice straw-based silage reduced fibrous components i.e. NDF and ADF, enhanced lactic acid concentration and OM digestibility (in vitro). The mixture silage of FRS, TW, CW in the ratio of $40: 20: 40$ with addition of LAB inoculant (silage B) resulted a better fermentation quality and in vitro digestibility.

\section{ACKNOWLEDGEMENT}

This study was funded by the Directorate General of Higher Education, Indonesian Ministry of Education and Culture (Contract No. 040/SP2H/PL/Dit. Litabmas/IV/2011).

\section{REFERENCES}

Ando, S., M. Ishida, S. Oshio \& O. Tanaka. 2006. Effects of isolated and commercial lactic acid bacteria on the silage quality, digestibility, voluntary intake and ruminal fluid characteristics. Asian-Australas. J. Anim. Sci. 19:386-389. http://dx.doi.org/10.5713/ajas.2006.386

Antaribaba, M. A., N. K. Terro, B. Tj. Hariadi \& B. Santoso. 2009 Pengaruh taraf inokulan bakteri asam laktat dari ekstrak rumput terfermentasi terhadap kualitas fermentasi silase rumput raja. JITV 14:278-283.

AOAC. 2005. Official Methods of Analysis, 17th ed. AOAC International, Washington.

Bureenok S., T. Namihira, S. Mizumachi, Y. Kawamoto \& T. Nakada. 2006. The effect of epiphytic lactic acid bacteria with or without different byproduct from defatted rice bran and green tea waste on napiergrass (Pennisetum purpureum Shumach) silage fermentation. J. Sci. Food Agric. 86:1073-1077. http://dx.doi.org/10.1002/jsfa.2458

Cao, Y., T. Takahashi, K. Horiguchi \& N. Yoshida. 2010. Effect of adding lactic acid bacteria and molasses on fermentation quality and in vitro ruminal digestion of total mixed ration silage prepared with whole crop rice. Grassland Sci. 56:1925. http://dx.doi.org/10.1111/j.1744-697X.2009.00168.x

Chamberlain, A.T. \& J. M. Wilkinson. 1996. Feeding the Dairy Cow. Chalcombe Publications, Lincoln, UK.

Danner, H., M. Holzer, E. Mayrhuber \& R. Braun. 2003. Acetic acid increases stability of silage under aerobic conditions. Appl. Environt. Microbiol. 69:562-567. http://dx.doi. org/10.1128/AEM.69.1.562-567.2003

de Oliveira, S. G., T. 'T. Berchielli, R. A. Reis, M. E. Vechetini \& M. S. Pedreira. 2009. Fermentative characteristics and aerobic stability of sorghum silages containing different tannin levels. Anim. Feed Sci. Technol. 154: 1-8. http://dx.doi. org/10.1016/j.anifeedsci.2009.07.003

Hariadi, B. Tj. \& B. Santoso. 2010. Evaluation of tropical plants containing tannin on in vitro methanogenesis and fermentation parameters using rumen fluid. J. Sci. Food. Agric. 90:456-461.

Horiguchi, K. \& T. Takahashi. 2007. Fermentation quality and nutritive value of green soybean stover silage. Grassland Sci. 53:27-31. http://dx.doi.org/10.1111/j.1744697X.2007.00070.x

Givens, D. I. \& H. Rulquin. 2004. Utilization by ruminants of nitrogen compounds in silage-based diet. Anim. Feed Sci. Technol. 114: 1-18. http://dx.doi.org/10.1016/ j.anifeedsci.2003.09.005

Kawamoto, H., R. Otani, A. Oshibe, H. Yamaguchi, S. Deguchi, O. Tanaka, S. Ouzumi \& H. Watanabe. 2007. Ensilage of wilted whole crop rice (Oryza sativa L.) using a roll baler for chopped material: Silage quality in long-time storage. Grassland Sci. 53: 85-90. http://dx.doi.org/10.1111/j.1744697X.2007.00077.X

Li, J., Y. Shen \& Y. Cai. 2010. Improvement of fermentation quality of rice straw silage by application of a bactrial inocolant and glucosa. Asian-Australas. J. Anim. Sci. 23:901-906. http://dx.doi.org/10.5713/ajas.2010.90403

McDonald, P., A. R. Hunderson \& S. J. E. Heron. 1991. The Biochemistry of Silage, 2nd edn. Cambrian Printers Lt. Aberystwyth.

McDonald, P., R. A. Edwards \& J. F. D. Greenhalgh. 1987. Animal Nutrition, 4th edn. Longman Group Ltd. Hongkong.

Santoso, B. \& B. Tj. Hariadi. 2009. Evaluation of nutritive value and in vitro methane production of feedstuffs from agricultural and food industry by-products. J. Indon. Trop. Anim. Agric. 34:190-196.

Santoso, B., B. Tj. Hariadi, Alimuddin \& D. Y. Seseray. 2012. Fermentation characteristics of rice crop residue-based silage treated by epiphytic and comercial LAB. Med. Pet. 34:140-145. http://dx.doi.org/10.5398/medpet.2011.34.2.140

Santoso, B., B. Tj. Hariadi, H. Manik \& H. Abubakar. 2011a. Silage quality of king grass (Pennisetum purpureophoides) treated with epiphytic lactic acid bacteria and tannin of acacia. Med. Pet. 34:140-145. http://dx.doi.org/10.5398/ medpet.2011.34.2.140

Santoso, B., B. Tj. Hariadi, H. Manik \& H. Abubakar. 2009. Kualitas rumput unggul tropika hasil ensilase dengan bakteri asam laktat dari ekstrak rumput terfermentasi. Med. Pet. 32:138-145.

Santoso, B., B. Tj. Hariadi, Alimuddin \& D. Y. Seseray. 2011b. Kualitas fermentasi dan nilai nutrisi silase berbasis sisa tanaman padi yang diensilase dengan penambahan inokulum bakteri asam laktat epifit. JITV 16:1-8.

Sebolai, T. M., A. A. Aganga, N. Nsinamwa \& J. C. Moreki. 2012. Effect of diffrent silage preservatives on silage quality of Pennisetum purpureum harvested at different harvesting periods. J. Anim. Feed Res. 2: 139-144.

Takahashi, T., K. Horiguchi \& M. Goto. 2005. Effect of crushing rice and the addition of fermented juice of epiphytic lactic acid bacteria on the fermentation quality of whole crop rice silage, and its digestibility and rumen fermentation status in sheep. Anim. Sci. J. 76:353-358. http://dx.doi. org/10.1111/j.1740-0929.2005.00275.x

Van Soest, P. J., J. B. Robertson \& B. A. Lewis. 1991. Methods for dietary fiber, neutral detergent fiber, and nonstarch polysaccharides in relation to animal nutrition. J. Dairy Sci. $\quad 74: 3583-3597 . \quad$ http://dx.doi.org/10.3168/jds.S00220302(91)78551-2

Wang, J., J. Q. Wang, H. Zhou \& T. Feng. 2009. Effects of addition of previously fermented juice prepared from alfalfa on fermentation quality and protein degradation of alfalfa silage. Anim. Feed Sci.Technol. 151:280-290. http://dx.doi. org/10.1016/j.anifeedsci.2009.03.001

Weinberg, Z. G., R. E. Muck, P. J. Weimer, Y. Chen \& M. Gamburg. 2004. Lactic acid bacteria used in inoculants for silage as a probiotics for ruminants. Appl. Biochem. Biotech. 118: 1-10. http://dx.doi.org/10.1385/ABAB:118:1-3:001

Yahaya, M. S., M. Goto, W. Yimiti, B. Smerjai \& Y. Kuwamoto. 2004. Evaluation of fermentation quality of a tropical and temperate forage crops ensiled with additives of fermented juice of epiphytic lactic acid bacteria (FJLB). Asian-Australas. J. Anim. Sci. 17:942-946.

Zhang, Y. G., H. S. Xin \& J. L. Hua. 2010. Effects of treating whole-plant or chopped rice straw silage with different levels of lactic acid bacteria on silage fermentation and nutritive value for lactating Holstein. Asian-Australas. J. Anim. Sci. 23: 1601-1607. http://dx.doi.org/10.5713/ ajas.2010.10082 